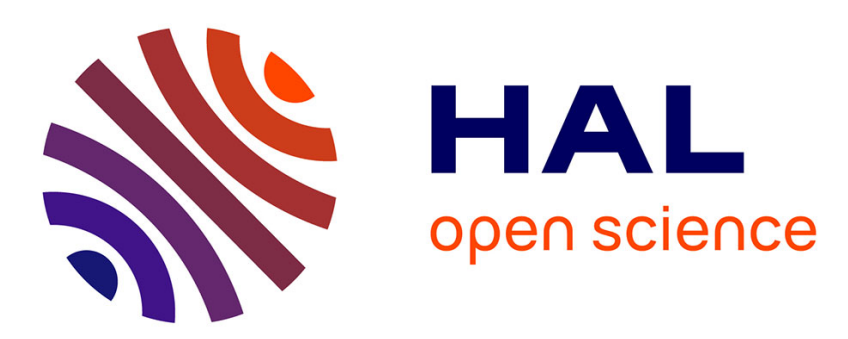

\title{
One of Us? From Bad Taste to Empathy, Otherness in Contemporary Hollywood Movies
}

\author{
Adrienne Boutang
}

\section{To cite this version:}

Adrienne Boutang. One of Us? From Bad Taste to Empathy, Otherness in Contemporary Hollywood Movies. Recherches Semiotiques Semiotic Inquiry, 2013, Care et cinéma, 30 (1-2-3), 10.7202/1025923ar . hal-03561784

\section{HAL Id: hal-03561784 \\ https://hal.science/hal-03561784}

Submitted on 8 Feb 2022

HAL is a multi-disciplinary open access archive for the deposit and dissemination of scientific research documents, whether they are published or not. The documents may come from teaching and research institutions in France or abroad, or from public or private research centers.
L'archive ouverte pluridisciplinaire HAL, est destinée au dépôt et à la diffusion de documents scientifiques de niveau recherche, publiés ou non, émanant des établissements d'enseignement et de recherche français ou étrangers, des laboratoires publics ou privés. 


\title{
One of Us? From Bad Taste to Empathy, Otherness in Contemporary Hollywood Movies
}

\author{
Adrienne Boutang \\ Sorbonne Nouvelle University - Paris III
}

One of the essential principles of "care" is to admit the fact that vulnerability, and thereby dependency, is not an exception to the rule, but is a universal characteristic of manhood. It also implies an ability to empathize with alterity, and consider other people's pain and emotions, however different, as deserving attention and comprehension. Very recently, in American mainstream cinema, a new stream of light comedies - the "gross out" comedies, more famous for their use of vulgar humor and general bad taste - has precisely tried to tackle the problem of alterity, and to question the distinction between normality and monstrosity. How is mainstream cinema supposed to "deal" with the subject of alterity, and especially, physical deformity?

The gross out movie genre in contemporary American cinema offers a different vision of the body than what can be found in other genres of mainstream cinema - an aesthetic, or rather a counter aesthetic - of bad taste, aiming at provoking disgust in the minds - and bodies - of its viewers, and claiming a vision of the body heavily physiological. The genre thus allows explorations and representations that are hard to find anywhere else in Hollywood territory, constituting thereby a space of freedom and an alternative. What has been most interesting in the evolution of the genre, especially under the seminal influence of the Farrelly brothers, from the 1990s on, is the way this bad taste genre has been used, even in the mainstream, to question and play with the categories defined as delicate by the codes of political correctness. This irreverent approach, walking a fine line between the acceptable and the shocking, might, as we will try to argue here, be seen as a way to question the inherent limits of Hollywood's classical way of dealing with alterity, and thereby as a means towards a recognition of the vulnerable otherness that is usually denied.

\section{Hollywood Norm, Between Performance and Reverence - Denial or Caring?}

Let us begin by reminding what are the implicit rules that regulate the representation of physical "otherness" in American recent main- stream films. 
it more palatable for a large audience - has been to privilege psychic or intellectual troubles over physical deformities. Mental disabilities or diseases - madness, or slight intellectual deficiencies - seem easier to deal with than physical deficiencies, which raise issues of representation. The portrayal of mental disabilities has often constituted a way to bring out great performances from actors, seizing this opportunity to push the boundaries of the "method acting" by embodying a radical form of alterity. The impersonation of disability - or madness - thus becomes a display of mastery, of brilliant skill, on the part of the actor. One Flew Over the Cuckoo's Nest (Milos Forman 1975), has been, for instance, widely known for the spectacular performance given by Jack Nicholson. This particular movie also constituted an empathic immersion into the inner world of a disturbed mind, thus blurring the boundaries between rationality and madness. Jim Carrey's performance in Me, Myself and Irene (the Farrelly brothers 2000) can also be read as a demonstration of his chameleon-esque plasticity - though on a much lighter tone since schizophrenia loses any disturbing connotation to simply turn into a comic subject.

Equally spectacular are Dustin Hoffman's performance in Rainman (Barry Levinson 1989), or Tom Hank's in Forrest Gump (Robert Zemeckis 1994). Both make up for their main character's disability by two means : first, the virtuosity of the actors performing them, and second, the secret "talent" of their character, that will be revealed at some point. Mental disability thus appears to be played, performed, while "real" disabled people appear to be mere extras, briefly granting a touch of authenticity before being swiftly relegated to the background. This is indeed what happens in Rainman, which tells the story of the encounter between a yuppie (Tom Cruise) and his autistic brother - only one brief scene at the clinic features people that are really mentally diseased, and the rest of film precisely takes Raymond - and the viewer - in a road trip, far away from them.

Moreover, both movies tend to dismiss as much as possible more disturbing issues, as for instance intimacy and sexuality. Their main characters appear relatively sexless. But directors walk a much thiner line when it comes to representing physical disability.

\section{Reverence and Denial : The Bone Collector}

The norm in Hollywood seems to be to represent disability with an inevitable reverence which tend to limit the options for filmmakers willing to operate inside the boundaries of mainstream territory. On a strictly narrative point of view, narratives tend to present disabled bodies inside the fiction as the product of an accident rather than inborn, probably to ease the identification on the part of the viewer. Moreover, this narrative pattern implies that disability could happen to anyone, and 
therefore to remind a fundamental principle underling the ethics of "care" : the universality of vulnerability, and of dependency, which are seen as a general condition rather than as a exception to the rule. This is the case in The Bone Collector (Phillip Noyce 1999) and, more obviously, in Men of Honor, (George Tillman Jr. 2000), which connects the question of disability with racial issues. However, this vulnerability is also, in both movies, somehow denied, as disability is integrated in the optimistic arch of a narrative exploring the infinite possibilities of human nature and the importance of determination.

The Bone Collector tells the story of a tetraplegic detective who has been paralyzed from the neck down in an former accident and has to rely on machines and on his nurse to perform his professional duties and for his daily life. Although the film clearly exposes the character's disability, it also emphasizes the way his dependency is compensated by technological device - among which a powerful computer, and also a very helpful assistant, played by Angelina Jolie, whom he uses more or less as a living prosthesis at his service. Moreover, his sharpness of mind clearly makes up for his reduced physical condition, and, although the possibility of his becoming a "vegetable" often arises in the dialogs, this horrifying contingency, and the "temptation" of assisted suicide, is only briefly considered. Most of the time, the camera focuses on his quick-witted and intense face. The rest of his body only appears through poetical inserts for instance when, thinking he is asleep, Angelina Jolie's character softly caresses his hand - thereby bringing upon herself this sarcastic retort : "There are laws against molesting handicapped!". As can be seen in this example, the main character is the only one who refers directly to his condition, and is entitled to joke about it - except for the two villains, who take pleasure in reminding him of his disability in nasty terms, purposely picking humiliating expressions. The bad cop thus calls him a "fucking crippled". The movie clearly distances itself from any condescendence towards disability. When the body becomes prominent again in the story - when, for instance, the character suffers from suffocation - only his face appears in the frame, the rest of the body once again conveniently left offscreen.

Only in one very specific scene of the film is this cautious reverence, which somehow verges on denial, briefly forgotten, as the character's disabled body becomes part of a dramatic suspense moment. In this key scene, the serial killer pays a visit to the hero, bed bound and left alone in his apartment, with no one to take care of him. Here the disability of the character is used, both narratively and visually, as a suspense trick, emphasizing his fragility and dependency, and therefore increasing the suspense and the thrill of the fight to come, so obviously asymmetric. The villain takes advantage of the vulnerability of the character, thus clearly violating a taboo. He first unplugs the technological device, and then, 
proceeding to assault the real body of his victim, breaks his finger - the one used to activate the computer; after which he violently manipulates the device used to control the hero's blood pressure, causing him to jump, while asking him "what sort of vegetable [he] would rather be, carrot or zucchini". The hero nevertheless manages to keep fighting, at least until the most transgressive moment of the film - when then narrative abandons its strategies of "denial" of the disabled body, and briefly shows, in full shot, the hero falling over his bed. All is well that ends well, however, and soon enough he will be saved by the arrival of Angelina Jolie - but those few moments during which the "different body", instead of being treated with delicacy and deference, has been treated as less valuable than others, and its weakness shamelessly taken advantage of, is the most memorable of the movie. The next shot shows the character months later, having left his bed for a state of the art wheelchair - very elegant, smiling, and once again framed in close up, reinstated in society for good. The Hollywood movie thus "frames" the depiction of the disabled body, then briefly plays with the taboo of a violence directed at this vulnerable body, before, eventually, reverting to a more controlled representation, emphasizing the capacity of the hero for social integration and individual accomplishment. This is precisely what the gross out comedy, refusing the stereotypical reverence, will put into question, in the 1990's.

\section{Irreverence as a Weapon, Vulnerability as an Universal Quality : Positive Action, Care, and Gross Out in the 1990's}

In the 1990's mainstream cinema, especially through the comedies written and directed by the Farrelly brothers, a new approach of the representation of the disabled body began to develop, quite different from the alternative between reverence/absence which had until then been dominant - without, nonetheless, reverting to a freak show as could be found in the famous Todd Browning's movie. In movies like There's something about Mary (1998), or Shallow Hal (2001), among many others, disabled characters are often present, and treated in a way that is much more elaborate than what has been analyzed earlier as the "Hollywood" way. The boldness of the Farrelly brothers consists in two main elements : first, the fact that they don't hesitate to cast ac- tors that are disabled in real life, instead of resorting to performances. Second, their general refusal of the usual discreet reverence which is, as we have seen, used by most mainstream movies as a means to relegate in the background the body of the disabled character, therefore denying this bodily specificity. Their avoidance of the general conventions of representation has often caused those films to be labeled "bad taste" comedies, as the filmmakers were themselves accused of "exploiting" 
the disabled bodies as a way to get a few cheap laughs. However, under the obvious provocative dimension can be seen a much more militant ambition : correcting an absence, and give to those "obvious minorities" the visibility and audience that they are usually deprived of in mainstream movies. Indeed, the movies of the Farrelly brothers made way for a general acceptance, in the territory of "gross out" comedies, and among the usual "lavatorial humor" of the genre, of those different bodies, bringing with them their strange alterity which became part and parcel of the genre. Thus the gross out comedy has been turned as a tool of affirmative action, allowing those different bodies to be recognized in their alterity, and giving to disabled actors a range of roles much wider than the former ones - all this through the tool of provocation here used as a way to question the viewer's implicit prejudices and help them pass those prejudices.

\section{Irreverence in Fiction}

The first provocative element lies in the way disabled characters (either played by real disabled actors, or performed) are treated inside the narratives. It is very frequent to see disabled characters being more or less molested or at least verbally assaulted in the Farrellys' comedies. The fact that most of the time those assaults can be easily explained by a misunderstanding (Hollywood's old tool to make "transgressive" attitudes palatable for its viewers) doesn't make them less scandalous in the eyes of a viewer used to the usual "reverence" analyzed previously. $\mathrm{Me}$, Myself and Irene (2000) contains a scene which shows its character (Jim Carrey, here impersonating a schizophrenic character) violently assaulting an elegant car which has been parked - or so he thinks - on a parking space reserved for handicapped. It is only after he has urinated on the elegant car that he discovers that his owner is a man wearing an orthopedic corset and very visibly disabled. The character has therefore been led to violate a taboo - the delicacy with which one is expected to treat disability - but, as the viewer, to question his usual reflexes - why wouldn't a disabled man be the owner of an elegant sport car? Moreover, the disabled character has thereby been "normalized" as he becomes an acceptable target for bathroom humor, instead of being confined to classical "reverential" parts. The laugh works here as a factor of normalization of alterity - but it has to start with the transgression of a taboo.

The transgression is more frontal when the "villains" of the narratives, fully endorsing their "evilness", resort to disturbing terms to qualify those different bodies - for instance, the character of Healy, in There's something about Mary, trying to prove that he is a tolerant and caring person, is betrayed by his vocabulary, first saying that he "works with retards", before describing one of his so-called "friends" as having "a 
forehead like a drive-in theater leash", and calling them "goofy bastards". The mechanism seems to be identical to what happened in The Bone Collector : the character of the villain is used as a pretext to use pejorative vocabulary, which is usually banished from any regular conversation. However, the scene, in the Farrelly's comedy, lingers longer on the unpolitically correctness of the expressions, and seems to revel into this transgression of the taboo, using its villain character as a way to expose the prejudices of the villain, but also to question the slight feeling of shame experiences by the viewer as he laughs. If the target of the joke is obviously the villain, and not the disabled characters he is insulting, the simple use of pejorative vocabulary is never quite harm- less, and always keeps some ambiguity. Things get worse when Healy takes advantage of the disability of his fellow companions to win quite underserved victories, at soccer games for instance. This specific scene is more disturbing because, even though the blame is once again on Healy, the target of the humor is mode ambiguous, and may remind the viewer of "old jokes" mocking the diminished capacities of disabled individuals. For instance, during the soccer game, Healy knocks down each disabled member of the team as if all of them were but a bunch of skittles, before luring one of them into running towards him, and watch him heavily falling at his feet. What the film offers here is a restoration of the law of the jungle, in which the weak are defeated; besides, the filmmakers do their best to underline the situation visually, constructing a mise-enscène which accentuates the helplessness of the victims, and the absurdity of their behaviors - one of them is seen, wearing his orange overall, throwing himself from a high palm tree, screaming, with no apparent reason. Once again, the viewer's laugh is double edged - both targeted at the pettiness of the villain who shamelessly uses his physical and intellectual superiority, and, more ambiguously, at the clumsiness of the disabled characters around him. Half of the scene aims at discrediting the heartlessness of the villain, and conversely encouraging what could be accurately described as the impersonation of "care", through the "gentle" character of Mary, all empathy and delicate generosity. The character of Mary perfectly fits the definition of "gentleness" as exposed by Baier (1985 : 219), with her sweet ability to be generous without a hint of condescendence. But this obvious model, with all her good spiritedness, is somehow contradicted by the obvious pleasure taken by the film in torturing - however inconsequently - his disabled characters, and using them as comic props. When the films stop using the mediation of "villains" and starts using directly the disabled body as a source of classical slapstick humor - with its traditional Schadenfreude, this double edginess becomes even more confusing. 
The most disturbing scene of Mary is entirely built on the nasty laugh one gets at watching a misshapen man, "Tucker", walking on crutches, desperately trying to reach the floor where he just dropped his keys, while his friend, next to him, the sweet Mary, pays no attention to this everyday drama. The scene is filmed in long shot, with Mary on one side of the frame, and, on the other, Ted, standing, with great difficulty, on his crutches, his vulnerability and dependency emphasized by the low-angle view. The mixture of laughter and unease increases, as the incident goes on, allowing the "victim" (who is, as we will find out later in the movie, in fact performing his disability, even in the fiction) to wriggle about like a worm, leaning forwards, then backwards, squirming like a slapstick actor, while softly whining. It takes a while before Mary eventually gets up and comes and help him, in two stages : first she brings his keys closer, and then, seeing he is still incapable of picking the keys, puts them directly in his hands, as he boasts : "See? I knew I could do it." The running joke is not over, however, but continues in typical "slow burn" fashion, as Mary asks Tucker if he needs her to open the door for him, and we see poor Tucker, during one more excruciating minute, move to the next room, and collapse once more on his crutches, as Mary finally shuts the door, leaving him to his unhappy fate.

The scene, besides its undeniable comical efficiency, raises a few questions, without having to solve them - such is the privilege of the comic form. First, and once again through the character of Mary, here again representing the perfect attitude of caring solicitude, the limits of the will to treat disabled individuals as "regular" persons, thus denying their dependency; but the scene also points out the contradictions of generosity - at some point, despite all her good intentions, she ends up shutting the door at him, as if having exhausted all her generous resources. When - and how - to shut the door, when to pick up the keys - and, more importantly when to laugh, seem to be a couple of questions that aren't so easily solved. Even the rhythm of the scene, the choice to extend it way beyond the necessity of the gag, can be seen as a way to question the viewer's relationship towards vulnerability and suffering. The slow burn, the painful insistence on the physical efforts of the character, the refusal to put an end through a cut, is both a comical device and a way to force the viewer to experience, along with the character, physical limitations. The boldness of the sequence, and also its possible depth, lies both in this unexpected duration, and in the simple extension of the slapstick comic device to everybody, without any discrimination disabled or not. We will now focus on this singular "affirmative action" that can be seen to take place in the Farrelly brothers' movies.

\section{From Realistic Performances to Real Bodies}

The filmmakers frequently resort to actors that are really disabled, 
although sometimes alternating with actors performing as realistically as possible, different types of handicaps or deformities. In Shallow Hal, René Kirby, who suffers, as his character from spina bifida, plays one of the characters, "Walt", who is depicted as a womanizer, always dating beautiful women, thereby avoiding the status of laughable victim. However, as opposed to one happens in "regular" mainstream movie, the narrative and dialogs do not try to avoid the fact that his appearance might give rise to an instinctive feeling of strangeness, or even of disgust. Instead, in a way that is very typical of the "brothers" usual strategies, the film tackles the problem head-on, expressing that repulsed reaction through another character. Once it has been explicated, the disgust is quickly forgotten and reversed. Indeed, instead of accepting to be relegated in the role of the "freak", Walt is prompt to subvert the bathroom humor and to use it against others, as a weapon. As he puts on plastic gloves before entering the men's bathroom, he asks his bewildered companion: "You ever walked through a truck-stop men's room on your hands?". The lavatory humor is here used not against but by the disabled character, as a tool, eventually bringing him back to normality - like others he can joke about himself. Bad taste, bodily humor, and affirmative action all work together towards a normalization of the body formerly rejected.

\section{"One of Us"? Normalcy in Question}

To fully understand the mechanism of normalization which takes place in recent gross out comedies, one might compare their representation of physical deformity with the cult movie about otherness : Todd Browning's Freaks (1932). Freaks, as is well known, lies on a moral reversal : the "real" monsters are not the freaks, but the "normal" human being who behave without any sense of morality or human tenderness. Although playing on the fascination towards spectacular deformities, the film therefore constitutes a moral parable underlining the way appearances can be misleading, but mostly it questions the very dichotomy between normalcy and monstrosity.

One might quote Serge Daney, who writes, about Freaks, that "since 'men' and 'monster's can share a frame, they cease to be (men or monsters), what unites them becomes stronger than what separates them" (Daney 1983 : 20). Similarly, although in a lighter way, the narratives, in the Farrelly comedies, constantly resort to reversals, which keep exchanging the positions of normalcy and monstrosity. Mary's narrative perfectly exemplifies those carnivalesque reversals : right after the scene described earlier, one will learn that "Tucker" was a fake, only pretending to need crutches in order to attract Mary's pity and affection - thus taking shamelessly advantage of her good heart. Conversely, "normal" people will soon be found secretly suffering from a quite diverse amount of 
physical symptoms. The most spectacular shift involves a character who was supposed to personify normalcy : the character of Dom, who will, in the middle of the film, start showing a slight rash on his face - which will little by little invade his face and transform him into a monster, disfigured by huge red patches. If the monster is one of us, we, conversely, are very well exposed to becoming "one of them" - a fact that by separating too easily normalcy and monstrosity, through prejudice, or patronizing attitudes, we usually tend to forget. Far from being the exception, those reversals constitute a norm on which we might reconsider our general perspective on so-called monsters.

Thus, those horrifying shifts are a living reminder of the fundamental principle of the ethics of care : the universal vulnerability - or, as the Farrelly would put it, the fact that each of us might, at some point, become the monster he used to feel estranged from. By helping us experience through both laugh and empathy - this strange alterity, instead of trying to contain it, to frame it in the comfortable boundaries of good taste, the gross out comedy thus remind us of the general connections relating us to others - even if it means that we might all, at some point, become the target of a bad joke. 